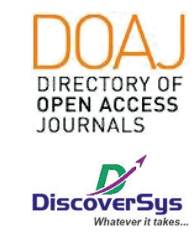

Published by DiscoverSys

\section{Hubungan kadar hemoglobin dengan kejang demam pada anak usia balita di RSUD Wangaya}

\author{
Komang Tria Anggareni, ${ }^{*}$ I Wayan Bikin Suryawan
}

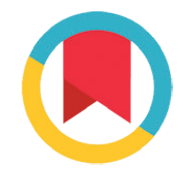

CrossMark

\title{
ABSTRAK
}

Latar Belakang: Sekitar 2-4\% anak berumur 6 bulan hingga 5 tahun mengalami kejang demam dengan puncak insiden pada usia 18 bulan. Begitu pula halnya anemia, anak usia 6 hingga 30 bulan memiliki kadar hemoglobin terendah. Tujuan dari penelitian ini adalah untuk mengidentifikasi hubungan antara kadar hemoglobin dengan kejang demam.

Metode: Penelitian ini merupakan penelitian analitik observasional dengan rancangan penelitian potong lintang (cross-sectional) dilakukan di Ruang Kaswari RSUD Wangaya pada Bulan Agustus 2019. Pasien anak usia 6 bulan hingga 5 tahun dengan demam $>38^{\circ} \mathrm{C}$ dengan kejang atau tanpa kejang yang dirawat inap yang memenuhi kriteria inklusi dan eksklusi dimasukan ke dalam sampel dengan teknik consecutive sampling. Analisis bivariate dilakukan dengan uji Chi-square.
Hasil: Dari 46 sampel yang didapat 20 pasien (43\%) merupakan kejang demam, dan 26 pasien (57\%) demam tanpa kejang. Pada kedua kelompok memiliki proporsi jumlah sampel laki-laki yang tidak jauh berbeda $60 \%$ dan $69 \%$ begitu pula dengan sampel perempuan. Kelompok usia terbanyak adalah kelompok usia 1-2 tahun yang mendominasi sekitar 37\% dari sampel. Sebagian besar infeksi yang mendasari adalah infeksi saluran napas yaitu sekitar 35\%. Hasil dari analisis uji Chi-square didapatkan hubungan yang signifikan antara kadar hemoglobin dan kejang demam $(p<0,05)$.

Simpulan: Ditemukan hubungan yang signifikan antara kadar hemoglobin yang rendah dengan kejang demam. Penelitian dengan rancangan prospektif perlu dilakukan untuk memastikan kadar hemoglobin sebagai faktor resiko kejang demam.
Departemen IImu Kesehatan Anak, Rumah Sakit Umum Daerah (RSUD) Wangaya, Denpasar, Bali, Indonesia

*Korespondensi:

Komang Tria Anggareni, Departemen Ilmu Kesehatan Anak, Rumah Sakit Umum Daerah (RSUD) Wangaya, Denpasar, Bali, Indonesia taanggareni@gmail.com

Diterima: 30-08-2019 Disetujui: 28-06-2020 Diterbitkan: 01-08-2020

Kata kunci: hemoglobin, kejang demam, balita

Cite Pasal Ini: Anggareni, K.T., Suryawan, I.W.B. 2020. Hubungan kadar hemoglobin dengan kejang demam pada anak usia balita di RSUD Wangaya. Intisari Sains Medis 11(2): 728-731. D0I: 10.15562/ism.v11i2.596

\section{PENDAHULUAN}

Sekitar 2-4\% anak berumur 6 bulan hingga 5 tahun mengalami kejang demam. Menurut American Academy of Pediatrics (AAP), kejang demam adalah kejang terjadi saat demam pada anak usia antara 6 hingga 60 bulan tanpa bukti adanya infeksi intrakranial, gangguan metabolik, dan riwayat kejang tanpa demam sebelumnya. ${ }^{1}$

Setiap negara memiliki angka kejadian yang berbeda-beda. Di Amerika Serikat dan Eropa Barat, kejang demam terjadi 2-5\%. Insiden kejang deman di Asia lebih tinggi, di Jepang terjadi sekitar 5-10\%, India 7-10\%, dan bahkan Guan mencapai hingga $14 \% .^{2}$ Kejang demam sering terjadi pada anak usia 6 bulan hingga 3 tahun dengan puncak insiden pada usia 18 bulan. ${ }^{1}$ Begitu pula halnya anemia, dimana $70 \%$ anemia terjadi pada anak usia 6 bulan hingga 5 tahun. Anak usia 6 hingga 30 bulan memiliki kadar hemoglobin terendah.,

Diperkirakan sekitar 20\% anak di Amerika akan mengalami anemia pada suatu titik tertentu pada masa kanak-kanaknya. Anemia secara umum didefinisikan sebagai penurunan konsentrasi sel darah merah atau konsentrasi hemoglobin. ${ }^{5}$

Penelitian Dasmayanti menemukan bahwa salah satu faktor risiko terjadinya kejang demam adalah anemia, terutama yang paling banyak ditemukan di Indonesia adalah anemia defisiensi besi. ${ }^{2}$ Hemoglobin adalah komponen sel darah merah terdiri dari protein kaya akan zat besi, berperan sebagai pengangkut oksigen dalam pembuluh darah. ${ }^{5,6}$ Oksigen dibutuhkan dalam proses transport aktif ion $\mathrm{Na}-\mathrm{K}$ yang berguna untuk menstabilkan membran sel saraf. Kestabilan membran sel saraf yang terganggu dapat mengakibatkan konsentrasi ion $\mathrm{Na}$ intrasel meningkat sehingga terjadi perubahan permeabilitas sel saraf sehingga terjadi depolarisasi yang berlebihan. ${ }^{2,7}$

Berdasarkan uraian di atas, peneliti tertarik untuk melakukan penelitian lebih lanjut, terkait dengan hubungan kadar hemoglobin dengan kejang demam pada anak usia balita di RSUD Wangaya.

\section{METODE}

Penelitian ini merupakan penelitian analitik observasional dengan rancangan penelitian potong lintang (cross-sectional). Penelitian ini mengkaji hubungan antara kadar hemoglobin dengan kejang demam. Penelitian dilakukan di ruang Kaswari RSUD Wangaya pada bulan Agustus 2019.

Pasien anak usia 6 bulan hingga 5 tahun dengan demam $>38^{\circ} \mathrm{C}$ dengan kejang atau tanpa kejang yang dirawat inap dan dengan hasil pemeriksaan 
hemoglobin yang terlampir pada rekam medis dimasukkan ke dalam sampel. Pasien dengan hemokonsentrasi, dehidrasi, dan status gizi buruk dilakukan eksklusi. Pemilihan sampel ditentukan dengan cara consecutive sampling. Selain kadar hemoglobin, data lain seperti jenis kelamin, usia, dan infeksi yang mendasari demam juga dikumpulkan.

Analisis bivariate dilakukan dengan analisis Chi-square menggunakan Statistical Product and Service Solution (SPSS) 24 for Mac. Penelitian ini dilaksanakan setelah memperoleh ethical clearance dan dilaksanakan dengan prinsip anonymity (tanpa nama) dan confidentiality (kerahasiaan).

\section{HASIL}

Pada penelitian ini didapatkan 46 pasien demam sebagai sampel dimana 20 pasien (43\%) dengan kejang, dan 26 pasien (57\%) tanpa kejang. Tabel 1 menunjukkan karakteristik sampel berdasarkan jenis kelamin, usia dan infeksi yang mendasari.

Pada kedua kelompok baik pada kejang demam maupun demam tanpa kejang memiliki proporsi jumlah sampel laki-laki yang tidak jauh berbeda
$60 \%$ dan $69 \%$ begitu pula dengan sampel perempuan. Kelompok usia terbanyak adalah kelompok usia 1-2 tahun yaitu sekitar 37\% dari sampel. Sebagian besar infeksi yang mendasari adalah infeksi saluran napas yaitu sekitar $35 \%$.

Tabel 2 menunjukkan hubungan yang signifikan antara kadar hemoglobin dan kejang demam. Analisis ini dilakukan menggunakan uji chi-square, dan didapatkan nilai $p$ lebih kecil dari 0,05, maka dapat diambil kesimpulan terdapat hubungan antara kadar hemoglobin dengan kejang demam.

\section{PEMBAHASAN}

Karakteristik sampel berdasarkan jenis kelamin sesuai dengan penelitian yang dilakukan oleh Kanis dkk. yang menemukan Distribusi jenis kelamin subjek laki-laki pada kelompok kasus lebih banyak dibanding subjek perempuan. ${ }^{8}$ Namun hal ini bertentangan dengan penelitian oleh Yunita dkk. dimana didapatkan lebih dari sebagian kejang demam terjadi pada pasien perempuan. ${ }^{9}$ Penelitian Verity dkk. menyimpulkan bahwa jenis kelamin tidak berkatan dengan kejang demam. ${ }^{10}$

\section{Tabel 1 Karakteristik sampel}

\begin{tabular}{lccc}
\hline Karakteristik & $\begin{array}{c}\text { Kejang Demam } \\
\mathbf{n}(\%)\end{array}$ & $\begin{array}{c}\text { Demam tanpa Kejang } \\
\mathbf{n}(\%)\end{array}$ & Total \\
\hline Jenis Kelamin & & & \\
$\quad$ Laki-laki & $12(60)$ & $18(69)$ & $16(35)$ \\
Perempuan & $8(40)$ & $8(31)$ & $7(15)$ \\
Usia & & & $17(37)$ \\
< 1 tahun & $5(25)$ & $2(7)$ & $11(24)$ \\
1-2 tahun & $8(40)$ & $9(35)$ & $10(22)$ \\
2-4 tahun & $4(20)$ & $7(27)$ & $1(2)$ \\
4-5 tahun & $3(15)$ & $7(27)$ & $16(35)$ \\
5-6 tahun & $0(0)$ & $1(4)$ & $5(11)$ \\
Infeksi yang Mendasari & & $11(43)$ & $3(6)$ \\
Infeksi saluran napas & $5(25)$ & $4(15)$ & $10(22)$ \\
Infeksi saluran pencernaan & $1(5)$ & $2(7)$ & $1(2)$ \\
ISK & $1(5)$ & $7(27)$ & $11(24)$ \\
Otitis & $3(15)$ & $1(4)$ & $1(4)$ \\
Lain-lain & $0(0)$ & $10(50)$ &
\end{tabular}

Tabel 2 Hubungan antara kadar hemoglobin dengan kejang demam

\begin{tabular}{lcccc}
\hline Kadar Hemoglobin & $\begin{array}{c}\text { Kejang Demam } \\
\mathbf{n}(\%)\end{array}$ & $\begin{array}{c}\text { Demam tanpa Kejang } \\
\mathbf{n}(\%)\end{array}$ & $\begin{array}{c}\text { Total } \\
\mathbf{n}(\%)\end{array}$ & $\mathbf{p}$ \\
\hline$\leq 11 \mathrm{~g} / \mathrm{dL}$ & $11(65)$ & $6(35)$ & $17(37)$ & 0,026 \\
$>11 \mathrm{~g} / \mathrm{dL}$ & $20(69)$ & $20(69)$ & $29(63)$ & \\
\hline
\end{tabular}


Pada penelitian ini didapatkan pada kelompok usia 1-2 tahun merupakan kelompok usia terbanyak mengalami kejang demam. Fuadi dkk. menemukan pada kelompok kasus dan kontrol sebagian besar mengalami kejang pertama kali pada usia kurang dari dua tahun. ${ }^{11}$ Dan pada penelitian Gontko-Romanowska K mendapatkan Sebagian besar pasien dengan kejang demam adalah pasien yang berusia $12-36$ bulan. ${ }^{12} \mathrm{Hal}$ ini sesuai dengan literature yang anak usia 6 bulan hingga 3 tahun merupakan kelompok usia yang paling rentan mengalami kejang demam dengan puncak insiden pada usia 18 bulan. ${ }^{1}$ Begitu pula halnya anemia, dimana $70 \%$ anemia terjadi pada anak usia 6 bulan hingga 5 tahun. Anak usia 6 hingga 30 bulan memiliki kadar hemoglobin terendah, sehingga mengalami kerentanan yang lebih tinggi. ${ }^{3,4}$

Infeksi yang paling banyak mendasari demam pada penelitian ini adalah infeksi saluran napas. Studi yang dilakukan oleh Gourabi mengatakan Infeksi virus pada saluran napas atas dan saluran pencernaan adalah penyebab tersering dari kejang demam. ${ }^{13}$ Hal ini sesuai juga dengan penelitian oleh Mahyar dkk. dan Kolahi dkk. ${ }^{14,15}$ Pada anak usia balita memang sering mengalami infeksi saluran napas sehingga menjadi infeksi yang paling banyak ditemukan pada kejang demam.

Pada penelitian didapatkan hubungan yang signifikan antara kadar hemoglobin dengan kejang demam. Banyak penelitian yang menyebutkan keterkaitan antara anemia defisiensi besi dengan kejang demam, dimana diketahui anemia defisiensi besi adalah anemia yang paling sering terjadi pada anak usia balita, akibat kebutuhan yang tinggi dan intake yang belum stabil. Ada beberapa kontroversi mengenai hubungan antara anemia defisiensi besi dengan kejangdian kejang demam. Pisacane, dkk menyebutkan kejadian anemia defisiensi besi sangat tinggi pada anak dengan kejang demam, namun Kobrinsky dkk. menyimpulkan defisiensi besi merupakan faktor protektif dengan meningkatkan ambang kejang. ${ }^{16,17}$ Penelitian ini merupakan penelitian retrospektif sehingga sulit mendapatkan pemeriksaan lab yang lebih lengkap seperti Serum Iron, TIBC yang merupakan marker defiensi besi.

Tanpa defisiensi besi, penurunan kadar hemoglobin sendiri dapat menurunkan ambang kejang pada anak. Pada anak yang mengalami anemia, kemampuan sel darah merah mengikat oksigen menurun. Oksigen berperan pada transport aktif ion $\mathrm{Na}-\mathrm{K}$ untuk menstabilkan membran sel saraf. Apabila hal ini terganggu dapat mengakibatkan konsentrasi ion $\mathrm{Na}$ di dalam sel meningkat sehingga mengakibatkan perubahan permeabilitas sel saraf sehingga terjadi depolarisasi yang berlebihan. ${ }^{2}$
Sehingga rentan terjadi kejang apabila anak mengalami demam tinggi.

\section{SIMPULAN}

Ditemukan hubungan yang signifikan antara kadar hemoglobin yang rendah dengan kejang demam. Penelitian dengan rancangan prospektif perlu dilakukan untuk memastikan kadar hemoglobin sebagai faktor resiko kejang demam.

\section{KONFLIK KEPENTINGAN}

Penulis menyatakan tidak terdapat konflik kepentingan terkait publikasi dari penelitian ini.

\section{PENDANAAN}

Penelitian ini tidak mendapatkan bantuan dana hibah dari pemerintah maupun sektor swasta lainnya.

\section{ETIKA DALAM PENELITIAN}

Penelitian ini telah mendapatkan persetujuan dari Komite Etik Fakultas Kedokteran Universitas Udayana/RSUD Wangaya.

\section{DAFTAR PUSTAKA}

1. AAP. Febrile Seizures: Clinical Practice Guideline for the Long-term Management of the Child With Simple Febrile Seizures. Pediatrics. 2008;121(6):1281-6.

2. Dasmayanti, dkk. Hubungan kadar hemoglobin dengan kejang demam pada anak usia balita. Sari Pediatri. 2015;16(5):351-5.

3. Alvarez-Uria G, dkk. Prevalence and severity of anaemia stratified by age and gender in Rural India. Anemia. 2014

4. Handoyo. Association between anemia and first-time febrile seizure: A case control study. J Indon Med Assoc. 2018;68(4):171-5.

5. Nathan and Oski. Hematology of Infancy and Childhood, 7th Edition. 2009.

6. Janus J dan Moerschel SK. Evaluation of anemia in children. American Family Physician. 2010;81(12):1462-71.

7. Putri LM. Hubungan anemia defisiensi besi dengan kejang demam pada anak balita. JMJ;5(1):68-77.

8. Khanis A. Defisiensi besi dengan parameter sTfR sebagai faktor risiko bangkitan kejang demam (Tesis). Semarang: Departemen Ilmu Kesehatan Anak Universitas Diponegoro, 2010.

9. Yunita VE, Afdal A, Syarif I. Gambaran faktor yang berhubungan dengan timbulnya kejang demam berulang pada pasien yang berobat di Poliklinik Anak RS. DR. M. Djamil Padang Periode Januari 2010-Desember 2012. Jurnal Kesehatan Andalas. 2016;5(3).

10. Verity CM, Butler NR, Golding J. Febrile convulsions in a national cohort followed up from birth. Br Med J. 1985;290:1307-10.

11. Fuadi, Bahtera T, Wijayahadi N. Faktor Resiko Bangkitan Kejang Demam Pada Anak. Sari Pediatri. 2010;12(3):142-9.

12. Gontko Romanowska K, Żaba Z, Panieński P. The assessment of laboratory parameters in children with fever and febrile seizures. Brain and Behavior. 2017;7(7). 
13. Gourabi H. Febrile seizure: demographic features and causative factors. Iranian J Child Neurol. 2012;6:33-7.

14. Abolfazl Mahyar et al. Risk Factors of the First Febrile Seizure in Iranian Children. International Journal of Pediatrics. 2010.

15. Kolahi AA, Tahmooreszadeh S. First febrile convulsions: inquiry about the knowledge, attitudes and concerns of the patients' mothers. European Journal of Pediatrics. 2009;168(2), 167.

16. Pisacane A, Sansone R, Impaglizzo N, Coppola A, Ronaldo P, D’Apuzzo A, et al. Iron deficiency anaemia and febrile convulsions: case-control study in children under 2 years. BMJ. 1996;313(7056):343.
17. Kobrinsky NL, Yager JY, Cheang MS, Yatscoff RW, Tenebein M. Does iron deficiency raise the seizure threshold? J Child Neurol. 1995;10(2):105-9.

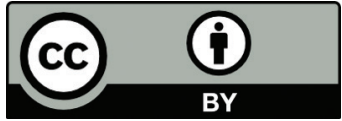

This work is licensed under a Creative Commons Attribution 